\title{
Urban Trees and Ecosystem Disservices- A Pilot Study Using Complaints Records from Three Swedish Cities
}

\author{
Tim Delshammar, Johan Östberg, and Cecilia Öxell
}

\begin{abstract}
Past research on urban ecosystem performance has focused mainly on ecosystem services, rather than disservices. However, to justify and fully utilize urban ecosystems, it is important also to assess and minimize the disservices they provide. The aim of this pilot study in Sweden was to contribute to the emerging understanding of urban ecosystem disservices. The central research question focused on how complaint/comment recordings at municipal park departments could be used as a source of knowledge on urban tree disservices. Records obtained from the municipal park departments in the three largest cities in Sweden provided evidence of several types of disservices. However, they also had obvious shortcomings that would need to be resolved before they could be used more widely as a source of information on ecosystem disservices. Suggestions for improving the data are provided.

Key Words. Municipal; Public Opinion; Sweden; Urban Tree Management.
\end{abstract}

Research on urban ecosystem functionality and performance to date has focused mainly on so-called 'ecosystem services'. Ecosystem services are the benefits people obtain from ecosystems and include provisioning services, such as food and water; regulating services, such as flood prevention; supporting services, such as soil formation; and cultural services, such as recreational benefits (MEA 2003).

In Sweden, as in many other countries, there is growing interest in spatial urban planning for ecosystem services (Colding and Marcus 2013). This requires systematic mapping of services (SOU 2013:68). This should also include factors that may decrease the services or produce so-called disservices. In a number of Swedish municipalities, non-systematic mapping of perceived problems or annoyances is carried out, as municipal park departments receive and record complaints and comments related to their urban greenspaces. The data are probably biased, as there tend to be differences between different groups in society in how they express their opinions (Statistics Sweden 2012). However, the data can still supply city personnel with useful data for tactical and strategic man- agement decisions. Development of urban greenspaces needs to be based on interactions between users and managers (Randrup and Persson 2009).

Disservices can be defined as "functions or properties of ecosystems that are perceived as negative for human well-being” (Lyytimäki and Sipilä 2009). Studies of single, isolated disservices are easy to find, whereas only a few studies have comprehensively analyzed urban ecosystem disservices (Dobbs et al. 2011). The concept of ecosystem disservices has been criticized, as it might be used to justify destruction of valuable ecosystem (Villa et al. 2014). The authors regard this a valid concern. However, spatial planning with a biased focus on servicesdisregarding possible disservices-could undermine the trustworthiness of ecosystem services as a planning concept in the long run (Lyytimäki and Sipilä 2009). Urban areas cover only a very small part of the earth and the urban ecosystems are to a large extent man-made. Thus, ecosystem services as well as disservices are important perspectives in urban green structure planning and management.

Any comprehensive study of disservices needs to rely on a theoretical framework, such as those sug- 
gested by the Millennium Ecosystem Assessment (MEA 2003) or The Economics of Ecosystems and Biodiversity (TEEB 2010). Some studies list a few disservices, without claiming to be comprehensive (Dobbs et al. 2011; Plieninger et al. 2013; Lyytimäki 2014). Others provide a more holistic framework [i.e., structured by the three pillars of sustainability (Escobedo et al. 2011) or are based on literature reviews but with no overall structure (Roy et al. 2012; Gómez-Baggethun and Barton 2013)].

These different descriptive classifications can be structured into three main approaches:

1. Based on ecosystem performance, for example generating pollen (Roy et al. 2012).

2. Based on disservices from ecosystems as experienced by humans, for example damage to infrastructure (Dobbs et al. 2011), habitat competition between humans and animals (Gómez-Baggethun and Barton 2013), fear of snakes (Lyytimäki 2014), etc.

3. Based on disservices deriving from human conduct and choices related to ecosystems, for example neglected and damaged urban green spaces (Plieninger et al. 2013).

Some studies also mention monetary costs (Escobedo et al. 2011; Roy et al. 2012).

Different methods have been used to assess disservices. Besides literature reviews, the methods include a survey on peoples' perceptions of disservices (Plieninger et al. 2013) and an indirect measurement through a study of newspaper coverage of disservices (Lyytimäki 2014). Dobbs et al. (2011) used different indicators known to be related to disservices; for example, the disservice 'Damage to infrastructure and risk to human safety' was assessed using data describing the number of tree species susceptible to damage. Thus, the methods vary from mapping perceived disservices to mapping their probable causes. This variation in methods represents a pragmatic approach, but lacks internal coherence and thus needs further development.

The aim of this pilot study was to investigate how urban ecosystem disservices are perceived by the public and if these perceptions can be assessed in a more systematic manner. The research question examined in the study was whether records of complaints/commentsheld at municipal park departments can be used as a source of knowledge on urban tree disservices.

\section{MATERIALS AND METHODS}

Records of complaints/comments received by the municipal park departments in the three largest cities in Sweden (Stockholm, Göteborg, and Malmö) in 2011 and 2012 were used as the empirical material for the study. The definition of disservices, suggested by Lyytimäki and Sipilä (2009) as "functions or properties of ecosystems that are perceived as negative for human well-being," was taken as a starting point. All complaints regarding trees in urban areas were considered as perceived preliminary evidence of ecosystem disservices from urban trees.

The initial intention of the study was to select items related to trees from the records. The records from Stockholm and Göteborg had a category labeled 'tree issues', but the records from Malmö did not distinguish this category. The authors therefore chose to select items that contained the word 'tree' instead. This yielded 1,931 items for Stockholm, 2,576 for Göteborg, and 1,665 items for Malmö. The table of urban ecosystem disservices suggested by Roy et al. (2012) was used as a starting point to classify the items into categories, as it appeared to be the most comprehensive method available. Each item was classified in two ways: type of episode and type of perceived disservice. The classification into episodes was used to describe what had happened in each case, the cause of the disservice. The classes of episodes were constructed inductively from the empirical data. The data collected by the municipal park department were intended to serve as the basis for direct actions to solve problems and not for indepth analysis, and therefore has shortcomings as a source of knowledge. The items mainly concerned trees, but also included, to some extent, shrubs and weeds. Some of the items were notes taken when a resident had called the municipal department. These were usually very short and written in telegram style-very short entries that sometimes had to be interpreted. Other items were e-mails sent by residents. These were sometimes very comprehensive, with extensive details on background and on how earlier complaints/comments had been handled. Initially, all authors classified 100 items each and the outcomes were compared and discussed to align the interpretations. The main part of the classification was made by one of the authors with profound knowledge of plant materials. 
Four categories of episodes were used to label urban tree disservices in this study:

A. 'Tree incident': when the item reported an unexpected episode (or the effect of an unidentified cause), such as a branch falling down.

B. 'Natural growth': when the problem reported concerned vegetation being, for example, too high or too wide.

C. 'Illness on tree': when reports concerned fungus on trees or leaves being visually affected by some kind of insect or disease.

D. 'Human misconduct': when the item referred to problems like vandalism or litter.

The categories were based on how the person reporting perceived the episode. Obviously, many tree incidents could have been caused by illness, human misconduct, or even natural growth. But this interpretation did not distinguish between episodes that had actually happened and episodes that were reported as likely (e.g., "a branch might fall down").

Each item classified as an episode according to this criteria was also classified as a type or sometimes several type(s) of disservice. This subsequent classification required varying degrees of interpretation, as the complaint records were not made with this kind of research aim in mind. For example, an item such as "branches hanging out on the sidewalk" was classified under the category 'Environmental problems/hazards'; subcategory 'Obstructing traffic on roads and sidewalks', even though the problem was not explicitly stated.

\section{RESULTS}

The most common complaint/comment overall, accounting for $33 \%$ of all requests, were directed toward municipal arborists. When only analyzing the urban tree disservice, the most common type of episode was 'Natural growth', accounting for
$30 \%$ of requests. The least common was 'Human misconduct', which accounted for 8\% (Table 1).

The most frequent urban tree disservice on record concerned 'Environmental problems/ hazards' (Table 2). There were no recorded items on either 'Economic problems/hazards' or 'Costs and expenditure'. The records on 'Social problems/ hazards' were solely restricted to the subcategory 'Causing fear of crime'. There were no records on 'Causing fear of diseases/insects/ other animals' in trees, forests, and associated environments. On the other hand, there were some records of related actual (not-feared) disservices within the category 'Health problems/ hazards'; i.e., the subcategories 'Increasing allergy attacks by plant pollens' (9 items), 'Increasing attack by associated insects and other animals' (63 items), and 'Risk of trees falling and causing personal injury' (191 items). Only two items concerned drainage problems caused by trees, an otherwise well-known problem.

\section{DISCUSSION}

The municipal records of complaints/comments received in Stockholm, Göteborg, and Malmö contained items that provided evidence of several types of perceived disservices. This pilot study confirmed that such data can help generate knowledge on how the public perceives urban ecosystem disservices.

There were many different causes for the disservices reported (Table 1). The fact that trees grow, becomelarge, and as a consequence, sometimes come into conflict with urban infrastructure is known, and future conflicts can be avoided by planners. Other types, such as illnesses and incidents are known to happen, but can be difficult to prevent. The last type of cause, 'Human misconduct', is not inherent to ecosystems, but rather occurs in an ecosystem setting. Thus it can be questioned whether this should be regarded as a perceived ecosystem disservice at

Table 1. Categories of episodes: recorded causes of perceived problems or annoyances related to trees in the Swedish cities of Göteborg, Malmö, and Stockholm.

\begin{tabular}{|c|c|c|c|}
\hline \multirow{2}{*}{$\begin{array}{l}\text { Causes of complaint/comment } \\
\text { Tree incident }\end{array}$} & \multicolumn{2}{|c|}{$\begin{array}{l}\text { No. of items } \\
\text { (\% of total) }\end{array}$} & \multirow{2}{*}{$\begin{array}{l}\text { Example of item } \\
\text { Two windthrown trees are blocking a footpath }\end{array}$} \\
\hline & 1,147 & $(19 \%)$ & \\
\hline Natural growth & 1,808 & $(30 \%)$ & Sidewalk overgrown \\
\hline Illness on tree & 634 & $(10 \%)$ & Suspected Dutch elm disease on tree \\
\hline Human misconduct & 481 & $(8 \%)$ & Graffiti on tree \\
\hline Comment/request & 2,049 & $(33 \%)$ & Cost of planting trees? \\
\hline Total number & 6,119 & $(100 \%)$ & \\
\hline
\end{tabular}


Table 2. Recorded problems or annoyances classified as disservices according to the categories suggested by Roy et al. (2012). Asterisk $\left(^{*}\right)$ indicates subcategories added in the present study.

\begin{tabular}{|c|c|c|}
\hline Disservice & $\begin{array}{l}\text { No. of items } \\
\text { (\% of total) }\end{array}$ & Example of item \\
\hline Social problems/hazards & $26(0.6 \%)$ & \\
\hline Causing fear of crime & $26(0.6 \%)$ & $\begin{array}{l}\text { Last Friday there was a severe assault in our park.... Preserve all the great } \\
\text { oaks but remove alder and other trees so the park can feel safe to visit. }\end{array}$ \\
\hline Economic problems/hazards & $\mathbf{0}(0 \%)$ & \\
\hline Health problems/hazards & $263(6.5 \%)$ & \\
\hline $\begin{array}{l}\text { Increasing allergy attacks by } \\
\text { plant pollens }\end{array}$ & $9(0.2 \%)$ & $\begin{array}{l}\text { Each summer, during the first week in June, flowering poplars release lots } \\
\text { of poplar fluff. Many say that they feel allergies when they come in contact } \\
\text { with the fluff. }\end{array}$ \\
\hline $\begin{array}{l}\text { Increasing attack by associated } \\
\text { insects and other animals }\end{array}$ & $63(1.6 \%)$ & $\begin{array}{l}\text { Have just cleaned the car of what must be the world's most expensive bird } \\
\text { droppings. The trees along the canal are a haven for all sorts of birds, and } \\
\text { this definitely causes a nuisance. }\end{array}$ \\
\hline Risk of trees falling and causing & $191(4.7 \%)$ & $\begin{array}{l}\text { At the southern aspect, a pine has been dead at the top for several years. } \\
\text { Now personal injury it seems the whole tree is going to die. We are afraid } \\
\text { that heavy snow in winter will crack more branches that can damage someone. }\end{array}$ \\
\hline $\begin{array}{l}\text { Visual and aesthetic } \\
\text { problems/hazards }\end{array}$ & $411(10.1 \%)$ & \\
\hline Darkness & $105(2.6 \%)$ & $\begin{array}{l}\text { Just outside our garden, we have a large tree with white flowers. This shades } \\
\text { most of our garden. }\end{array}$ \\
\hline $\begin{array}{l}\text { Displeasure with messiness } \\
\text { and clutter }\end{array}$ & $264(6.5 \%)$ & $\begin{array}{l}\text { In the spring, the tree drops a lot of flower debris and in autumn a lot } \\
\text { of leaves. }\end{array}$ \\
\hline Obscuring good views & $32(0.8 \%)$ & $\begin{array}{l}\text { The whitebeams have become incredibly large and dense, and one shades } \\
\text { the house. From the upstairs there is no longer a view of the street. }\end{array}$ \\
\hline $\begin{array}{l}\text { Drip sap or sticky residue } \\
\text { on parked cars }\end{array}$ & $7(0.2 \%)$ & $\begin{array}{l}\text { The trees shed seeds. It is no longer possible to park under the trees as } \\
\text { you have to wash the car every other day. }\end{array}$ \\
\hline Trees look ugly if not maintained & $3(0.1 \%)$ & $\begin{array}{l}\text { The trees between the houses are large and unkempt. Some are beginning } \\
\text { to hang out over the gardens, and some trees are dead and starting to lose } \\
\text { branches. Should be maintained! }\end{array}$ \\
\hline $\begin{array}{l}\text { Environmental } \\
\text { problems/hazards }\end{array}$ & $1,331(32.8 \%)$ & \\
\hline Causing drainage problems & $2(0.05 \%)$ & There are poplars that block the drains every year. \\
\hline Can fall across power lines & $33(0.8 \%)$ & $\begin{array}{l}\text { A dead elm has fallen in the storm and is hanging on the wire between the } \\
\text { lampposts. }\end{array}$ \\
\hline $\begin{array}{l}\text { Obstructing traffic on roads } \\
\text { and sidewalks }\end{array}$ & $782(19.3 \%)$ & The roots destroy the sidewalks. \\
\hline $\begin{array}{l}\text { Damage to buildings } \\
\text { and property }\end{array}$ & $185(4.6 \%)$ & A branch rubs the balcony when the wind blows. \\
\hline Damage to cars $^{\star}$ & $141(3.5 \%)$ & $\begin{array}{l}\text { Dead branches are falling down dangerously } \\
\text { close to parked cars. }\end{array}$ \\
\hline Concealing traffic signs ${ }^{*}$ & $95(2.3 \%)$ & Tree concealing traffic sign. \\
\hline Concealing lighting $^{*}$ & $78(1.9 \%)$ & Oak branches are concealing street lighting. \\
\hline $\begin{array}{l}\text { Obstructing use of spaces } \\
\text { (sports pit, parking lots)* }\end{array}$ & $15(0.4 \%)$ & There is a fallen pine covering a parking lot. \\
\hline Costs and expenditure & $\mathbf{0}(0 \%)$ & \\
\hline
\end{tabular}

all. What researchers can learn from the causes of disservices is that urban ecosystem disservices are partly an inevitable consequence of having ecosystems in urban areas and partly a planning, design, or management problem. Many conflicts between vegetation and infrastructure can be solved if best available knowledge is used. For example, if trees that do not grow too high or too wide are chosen for places where space is limited, there will probably be fewer conflicts between vegetation and infrastructure.
The most common perceived disservice mentioned in the material was 'Obstructing traffic on roads and sidewalks'. This might be one of the major urban ecosystem disservices, but its prevalence can also be the result of data bias. Obstructions in the transport infrastructure are easy to spot, typically need to be dealt with for safety reasons, and are therefore more likely to be reported. As most transport infrastructure is in the public domain, the most likely receiver of complaints/ 
comments is the public sector. Damage to buildings is also easy to spot, but most episodes of building damage probably do not involve municipal vegetation and are therefore not reported.

Other frequent disservices do not concern actual episodes, but rather the risk and fear of perceived likely episodes, such as the risk of personal injuries from falling trees or fear of crime. Although the trees concerned might never actually topple and crimes might never happen, fears affect people negatively.

When using the table of disservice categories suggested by Roy et al. (2012), the authors found that some of the disservices received no hits (Table 2). For example, there were no items concerning 'Economic problems/hazards' or 'Costs and expenditure'. This might be explained by the fact that costs are a problem for the park department, but that expenditure on park maintenance is typically only a small part of the municipal budget (Randrup and Persson 2009). It is also questionable whether costs should be regarded as a disservice at all. A municipal authority could argue that it chooses to use urban vegetation for the services it provides and therefore pays the costs for the provision of those services.

One subcategory with very few records concerned vegetation causing drainage problems, which is an otherwise well-known problem (Östberg et al. 2012). The lack of records on file might be explained by the fact that the problem is difficult for members of the public to spot until it is affecting the infrastructure or causing substantial problems.

What researchers can conclude from this pilot study of existing records of complaints/comments is that there are obvious shortcomings when it comes to the reliability of the method for collecting data and the validity of the data. The (current and potential) comprehensiveness of the dataset can also be debated. These are problems that have to be dealt with if better knowledge of perceived disservices is to be integrated into municipal greenspace management.

The shortcomings, as regards data reliability, are mainly due to the nonstandardized way of recording complaints/comments in the three cities investigated. By using standardized categories of disservices and follow-up questions, the procedure of recording complaints/comments could be made more reliable and the data obtained could be used for future planning. The cities investigated here use the complaints/comments to take immediate action, but not for tactical and strategic management decisions. Therefore, the same type of problems due to urban tree disservices might emerge over and over again.

The shortcomings, as regards data validity, are due to three theoretically unclear issues. The first of these is whether the reported disservice is an actual disservice, a possible future disservice, or a perceived disservice. There is a difference between, for example, a branch actually having fallen from a tree and obstructing traffic on roads and sidewalks and the possibility of a branch falling down. The second issue is whether the reported disservice is a disservice wherever it occurs, or rather only under specific circumstances. For example, a branch that falls might be a disservice if it obstructs traffic, but it might also be completely harmless, which again raises the question of whether it is an actual disservice or a perceived disservice. The third and final issue concerns whether the cause of the disservice is the ecosystem in itself or human misconduct related to the system. The subcategory 'Displeasure with messiness and clutter' is an example of the latter. A clearly perceived disservice, like 'fear of crime', has mainly societal causes. This means that such disservices may be perceived regardless of the properties of the ecosystem. 'Fear of crime' triggered by urban ecosystems is likely to vary between different societies and from one time to another.

Even with reliable recording and valid categories, there would still be the problem that records of complaints/comments probably do not provide a comprehensive picture of urban ecosystem disservices. Municipal records of complaints/comments are a passive system of assessment, based on what residents choose to complain/comment on. It is probable that those residents contributing complaints/comments are not a representative part of the population (Statistics Sweden 2012). No data were available on the contributing residents. It is also likely that there are a variety of issues to complain about, depending on whether a disservice is perceived as generated by an urban ecosystem or whether the ecosystem is considered a municipal responsibility. If these biases are taken into account, municipal records of complaints/comments can make an important contribution to creating a comprehensive knowledge base on urban ecosystem disservices. The data can also be used for comparisons over time and between different locations and eco- 
systems. Users' perceptions of urban ecosystemsservices or disservices-can give valuable input for decision making. With dynamic data sets, the planning, design, and management of ecosystems can be further professionalized and based on active inputs from park users (Randrup and Persson 2009). Finally, the approaches to frame ecosystem disservices are still very underdeveloped compared with that of services. A coherent approach could be mirroring the classification of services, with cultural ecosystem services relating to cultural ecosystem disservices and so forth. The issue of developing a coherent approach of ecosystem disservices should be addressed in future research.

It can be concluded that complaint/comment records at municipal park departments already give park managers a picture of how urban greenspaces provides disservices to urban dwellers. This picture is no doubt incomplete, but could be improved with a structured recording of the type of person (age, gender) who actually perceives disservices, the kinds of places in which the disservices are perceived, and full details of the kinds of disservices actually perceived. Structured recording would allow for continuous learning within municipal park departments and would also enable further research. The rapid development of communication technologies offers possibilities for fast and easy data collection from users. The challenge lies in interpreting the significance and universal applicability of the data.

Acknowledgments. This study was funded by Intereg IV A project Urban Transition Öresund and VINNOVA. We thank our colleagues Cecil Konijnendijk and Thomas B. Randrup for useful comments.

\section{LITERATURE CITED}

Colding, J., and J. Marcus. 2013. Ekosystemtjänster i Stockholmsregionen: Ett underlag för diskussion och planering (Ecosystem services in Stockholm: A basis for discussion and planning). Stockholm, Tillväxt, miljö och regionplanering, Stockholms läns landsting.

Dobbs, C., F.J. Escobedo, and W.C. Zipperer. 2011. A framework for developing urban forest ecosystem services and goods indicators. Landscape and Urban Planning 99:196-206.

Escobedo, F.J., T. Kroeger, and J.E. Wagner. 2011. Urban forests and pollution mitigation: Analyzing ecosystem services and disservices. Environmental Pollution 159:2078-2087.

Gómez-Baggethun, E., and D.N. Barton. 2013. Classifying and valuing ecosystem services for urban planning. Ecological Economics 86:235-245.
Lyytimäki, J. 2014. Bad nature: Newspaper representations of ecosystem disservices. Urban Forestry \& Urban Greening 13:418-424

Lyytimäki, J., and M. Sipilä. 2009. Hopping on one leg-The challenge of ecosystem disservices for urban green management. Urban Forestry \&Urban Greening 8:309-315.

MEA. 2003. Ecosystems and Human Well-being: A Framework for Assessment. Island Press, Washington, D.C. 160 pp.

Östberg, J., M. Martinsson, Ö. Stål, and A.M. Fransson. 2012. Risk of root intrusion by tree and shrub species into sewer pipes in Swedish urban areas. Urban Forestry \& Urban Greening 11:65-71.

Plieninger, T., S. Dijks, E. Oteros-Rozas, and C. Bieling. 2013. Assessing, mapping, and quantifying cultural ecosystem services at community level. Land Use Policy 33:118-129.

Randrup, T.B., and B. Persson. 2009. Public green spaces in the Nordic countries: Development of a new strategic management regime. Urban Forestry \& Urban Greening, 8:31-40.

Roy, S., J. Byrne, and C. Pickering. 2012. A systematic quantitative review of urban tree benefits, costs, and assessment methods across cities in different climatic zones. Urban Forestry \& Urban Greening 11:351-363.

SOU. 2013:68. Synliggöra värdet av ekosystemtjänster: åtgärder för välfärd genom biologisk mångfald och ekosystemtjänster: betänkande (Highlight the value of ecosystem services: Measures for wellfare by means of biodiversity and ecosystem services: report). Stockholm, Fritze.

Statistics Sweden. 2012. Svenskt valdeltagande under hundra år (One hundred years of Swedish voter turnout). Stockholm, Statistiska centralbyrån.

TEEB. 2010. The Economics of Ecosystems and Biodivesity: Mainstreaming the Economics of Nature: A synthesis of the approach, conclusions and recommendations of TEEB.

Villa, F., K.J. Bagstad, B. Voigt, G.W. Johnson, I.N. Athanasiadis, and S. Balbi. 2014. The misconception of ecosystem disservices: How a catchy term may yield the wrong messages for science and society. Ecosystem Services 10:52-53.

Tim Delshammar (corresponding author)

Swedish University of Agricultural Sciences

Landscape Architecture, Planning, and Management

P.O. Box 66

Alnarp 23053, Sweden

Johan Östberg

Swedish University of Agricultural Sciences

Landscape Architecture, Planning, and Management

Alnarp, Sweden

Cecilia Öxell

Swedish University of Agricultural Sciences

Landscape Architecture, Planning, and Management

Alnarp, Sweden 
Résumé. Les recherches antérieures sur la performance d'écosystèmes urbains portaient principalement sur les bénéfices générés par ces écosystèmes plutôt que sur les désagréments en découlant. Cependant, pour justifier et pleinement profiter des écosystèmes urbains, il convient également d'évaluer et d'atténuer les désavantages qu'ils engendrent. Le but de cette étude pilote suédoise était de contribuer à la compréhension croissante des désavantages présentés par divers écosystèmes urbains. La principale préoccupation de la recherche était axée sur la pertinence d'utiliser les données (plaintes et commentaires d'usagers) recueillies auprès de services de parcs municipaux, comme source de caractérisation pour les désagréments occasionnés par les arbres urbains. Les données recueillies auprès des services de parcs municipaux dans les trois plus grandes villes de la Suède ont fourni des éléments corroborants pour plusieurs types de désavantages. Cependant, ces données montrent des lacunes évidentes qui devront être résolues avant qu'elles ne puissent être utilisées plus largement comme source d'informations sur les désavantages des écosystèmes urbains. Des suggestions pratiques dans le but d’améliorer les données sont fournies.

Zusammenfassung. Die vergangene Erforschung der Leistung urbaner Ökosysteme fokussierte hauptsächlich auf den Leistungen des Ökosystems statt dessen Nachteilen. Dennoch ist es wichtig, um die urbanen Ökosysteme voll zu nutzen und zu rechtfertigen, dass auch die Nachteile, die sie liefern untersucht und minimiert werden. Das Ziel dieser Pilotstudie in Schweden bestand darin, einen Beitrag zum besseren Verständnis der Nachteile urbaner Ökosysteme zu leisten. Die zentrale Frage bei der Erforschung fokussierte darauf, wie Beschwerden und Anmerkungen in dne kommunalen
Verwaltungen als eine Informationsquelle für Nachteile urbaner Bäume genutzt werden können. Die Aufzeichnungen von kommunalen Verwaltungen in den drei größten Städten Schwedens lieferten Informationen über einige Arten von Nachteilen. Wie auch immer, sie hatten auch einige offensichtliche Mängel, die zuerst beseitigt werden müssten, bevor sie im Weiteren als Informationsquelle zu Informationen über die Nachteile der Ökosysteme genutzt werden können. Vorschläge zur Verbesserung der Daten werden hier vorgestellt.

Resumen. Las investigaciones pasadas sobre los beneficios del ecosistema urbano se han centrado principalmente en los servicios ambientales, antes que en sus perjuicios. Sin embargo, para justificar y utilizar plenamente los ecosistemas urbanos, es importante también evaluar y minimizar los detrimentos que prestan. El objetivo de este estudio piloto en Suecia fue contribuir a la comprensión emergente de perjuicios de los ecosistemas urbanos. La pregunta central de la investigación se centró en cómo los registros queja / comentario en los departamentos municipales de parques podrían ser utilizados como una fuente de conocimiento sobre los perjuicios de los árboles urbanos. Los registros obtenidos de los departamentos municipales de parques en las tres ciudades más grandes de Suecia presentaron certidumbre de varios tipos de perjuicios. Sin embargo, esos registros también tenían deficiencias evidentes que tendrían que ser resueltos antes de que puedan ser utilizados más ampliamente como una fuente de información sobre los perjuicios de los ecosistemas. Se proporcionan sugerencias para la mejora de los datos. 